\title{
Carbon Nanotube-Mediated Labelling Platforms for Stem Cells
}

\author{
H. Gul-Uludag1,4, W. Lu' ${ }^{2}$, P. Xu' ${ }^{1}$, J. Xing ${ }^{3,6}$ and J. Chen ${ }^{1,4,5}$ \\ ${ }^{1}$ Department of Biomedical Engineering, University of Alberta, Edmonton, Alberta, \\ ${ }_{2}^{2}$ IntelligentNano Inc., Edmonton, Alberta, \\ ${ }^{3}$ Department of Laboratory Medicine and Pathology, \\ University of Alberta, Edmonton, Alberta, \\ ${ }^{4}$ Department of Electrical and Computer Engineering, \\ University of Alberta, Edmonton, Alberta, \\ ${ }^{5}$ National Institute of Nanotechnology, \\ ${ }^{6}$ Cross-cancer Institute, Edmonton, Alberta, \\ Canada
}

\section{Introduction}

The discovery of carbon nanotubes (CNTs) promised to revolutionize biomedical research by offering unique performance attributes inherent in their unique mechanical, electrical, optical and magnetic properties [1-6]. CNTs are highly anisotropic cylindrical nanostructures with lengths ranging from several hundred nanometres to several micrometres, and diameters of $0.4-100 \mathrm{~nm}$. CNTs can be classified as single-walled carbon nanotubes (SWNTs) or multi-walled carbon nanotubes (MWNTs), depending on the number of graphene layers which compose its structure.

CNTs are typically prepared using one of three methods: laser ablation [7], arc-discharge [8], and chemical vapor deposition (CVD) [9]. CVD, the most popular pathway of production, involves reacting a metal catalyst (such as nickel, cobalt with a hydrocarbon feedstock at high temperatures $\left(>800^{\circ} \mathrm{C}\right)$ to produce CNT. Both SWNTs and MWNTs, are commercially available in varying degrees of purity. Pristine CNT (non-purified and/or nonfunctionalised) are completely insoluble in all solvents -- a property which has generated some health concerns in terms of toxicity [10]. Therefore the functionalization of CNT is a key step towards novel biomedical applications. Advanced methods to chemical modification and functionalization have enabled solvation and dispersal of CNTs in water [11-13]. Properly functionalized CNT have a high propensity to cross cell membranes. Various functionalized SWNTs have been shown to transport various bio-molecules across into living cells without cytotoxicity [14, 15]. Nanospearing or nanopenetration molecular delivery, which relies on the penetration of magnetic carbon nanotubes (mCNTs) into cells by magnetic field exposure, was also recently suggested by Cai et al [3]. In this technique, a rotating magnetic field first guided CNTs to spear the cells. In a second step, a static field pulled CNT into the cells. The researchers have achieved unprecedented high molecular delivery efficiency into difficult-to-transfect cells such as primary mammalian neurons and 
B lymphocytes with high viability after transfection. In addition to providing a successful molecular delivery platform, CNTs have been also used for successful cellular labelling/tracking in recent years. CNTs coated with peptides have been reported to be successfully delivered and imaged in living human cervical cancer HeLa cells [16]. More interestingly, CNT fluorescence was detected and imaged from living Drosophila larva by using near-infrared (NIR) with no adverse effects on the viability and growth of the larva [17]. These recent findings prompted our group to investigate CNT-mediated labelling platforms for stem cell tracking.

One of potential applications of nanotechnologies in stem cell research is the noninvasive tracking of stem cells and progenitor cells transplanted in vivo. Hematopoietic stem/progenitor cells (HSPC) are the most common type of stem cells used for cellular therapies for many decades [18]. Transplantation of HSPC obtained from peripheral blood $(\mathrm{PB})$, bone marrow $(\mathrm{BM})$ or from umbilical cord blood $(\mathrm{CB})$ has been routinely used to rescue bone marrow function following high-dose chemotherapy for non-malignant and malignant hematologic disorders such as leukemias [19, 20]. Labelling HSPC and the consecutive non-invasive tracking in vivo following transplantation have become important in understanding HSPC homing/engraftment into BM and the therapeutic efficacy for future stem-cell-based therapies. The fate of transplanted stem cells or progenitor cells is generally assessed by labelling them in vitro with a fluorescent dye, thymidine analog, transfected gene such as LacZ, or green fluorescent protein (GFP). However, the methodology for real-time tracking of HSPCs in vivo is still lacking, which seriously restricts the progress of research. This chapter describes the evaluation of the uptake efficiency of fluorescein-isothiocyanate-labelled functionalized mCNT (FITC-mCNT) into HSPC and their effect on the HSPC properties.

\section{Materials and methods}

\subsection{Source and isolation of human CD34 ${ }^{+}$HSPC}

Peripheral blood leukapheresis product (LP) was obtained with the patients' informed consent (in accordance with the institutional guidelines approved by the Human Research Ethic Board of the University of Alberta) before cryopreservation. CB was collected immediately after delivery in a sterilized tube containing heparin $(1000 \mathrm{IU} / \mathrm{ml})$, and with the informed consent of the mother (in accordance with the institutional guidelines approved by the Health Research Ethics Board of the University of Alberta). Light density cells from CB and LP were obtained by Percoll density gradient centrifugation and enriched for $\mathrm{CD}_{3} 4^{+}$cells by immunoaffinity selection with MACS paramagnetic beads (Miltenyi Biotec, Auburn, CA, USA), according to the manufacturer's instructions [21]. The purity of isolated CB and $\mathrm{LP}$ CD34 $4^{+}$cells were $>95 \%$ and $>91 \%$, respectively, as determined by fluorescence-activated cell sorter (FACS) analysis.

\subsection{Synthesis of FITC-mCNT}

Single-walled mCNT containing Ni and $Y$ at the tip, with an average diameter of 1.2-1.5 nm and a length of 2-5 $\mu \mathrm{m}$, were obtained from Sigma-Aldrich (Ontario, Canada). These specific mCNT were chosen for our experiment because they have been used in magnetic-fielddriven biomolecule delivery with very high efficiency [3]. Compared to the reported methods, our synthesis of FITC-mCNT is much simpler and yet returns higher chemical yields [11]. As shown in figure 1, the mCNTs were oxidized to form carboxylic acid groups 
on the surface $[3,11,22-24]$, which were reacted with thionyl chloride and then 2_(ethylenedioxy)bis(ethylamine) to produce amine terminated nanotubes. The amine was then reacted with FITC to provide FITC-labelled highly water-soluble FITC-mCNT. Infrared (IR), X-ray photoelectron spectroscopy (XPS) and UV-vis spectroscopy were used to validate the chemical reactions of the intermediate and the final FITC-mCNT products.

1. Oxidation of the carbon nanotubes: The first oxidation step was carried out as described previously [3, 11, 22-24]. Briefly, the purchased carbon nanotubes (200 mg) were refluxed with $0.5 \mathrm{M} \mathrm{HNO}_{3}(100 \mathrm{ml})$ for $48 \mathrm{~h}$ to introduce carboxylic groups. After refluxing, the solution was diluted with deionized water, filtered over a $0.2 \mu \mathrm{m}$ polycarbonate filter (Millipore) and washed several times with deionized water. The sample was collected and dried overnight in a vacuum oven at $80^{\circ} \mathrm{C}$ to obtain mCNT $2(170 \mathrm{mg})$ (figure 1).

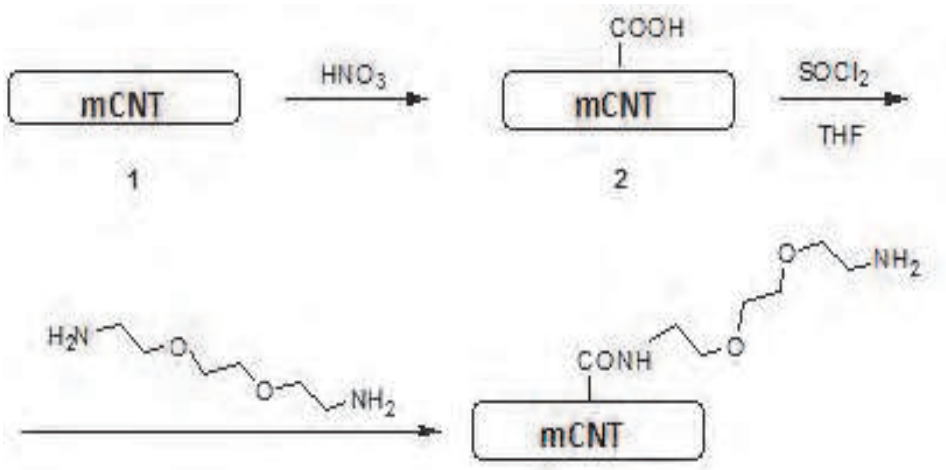

4

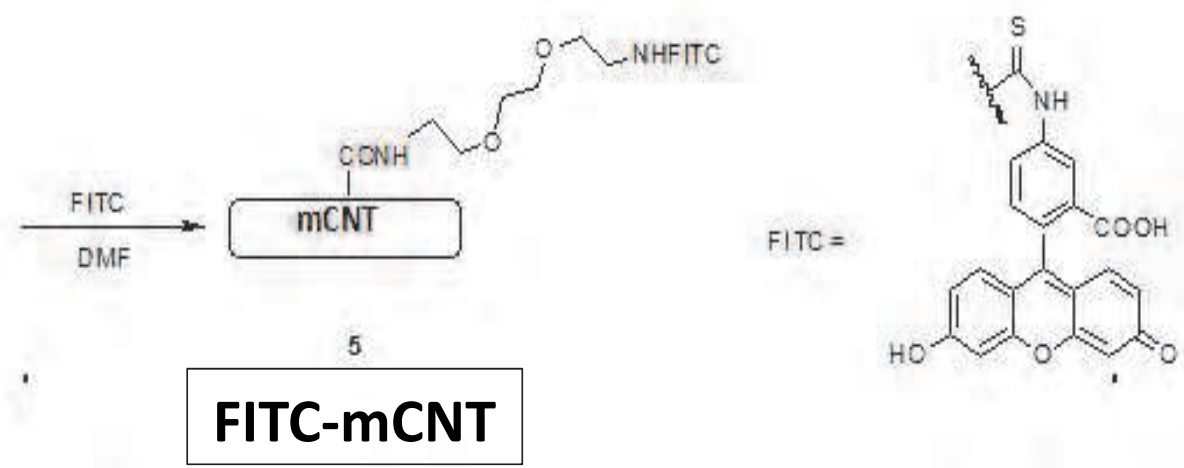

Fig. 1. Schematic illustration of FITC-mCNT synthesis. (1) The mCNTs were oxidized to form carboxylic acid groups on the surface. (2) These nanotubes were reacted with thionyl chloride, (3) and then 2_-(ethylenedioxy)bis(ethylamine) to produce amine-terminated nanotubes. (4) The amine was then reacted with FITCs to form highly water-soluble FITCmCNTs. (5) Freshly synthesized fluorescent and magnetic FITC-mCNTs were then used in magnetic-field-driven HSPC uptake experiments. 
2. Reaction with thionyl chloride to give SWNT-COCl: A suspension of $\mathrm{mCNT} 2(100 \mathrm{mg})$ in $20 \mathrm{ml}$ of $\mathrm{SOCl}_{2}$, together with five drops of dimethylformamide (DMF), was stirred at 70

- $\mathrm{C}$ for $24 \mathrm{~h}$. The mixture was cooled and centrifuged at $2000 \mathrm{rpm}$ for $30 \mathrm{~min}$. The excess $\mathrm{SOCl}_{2}$ was decanted and the resulting black solid was washed with anhydrous THF $(3 \times$ $20 \mathrm{ml}$ ) and dried overnight in a vacuum oven at $80^{\circ} \mathrm{C}$ to give $\mathrm{mCNT} 3(78 \mathrm{mg})$ (figure 1$)$.

3. Coupling with 2-(2-(2-aminoethoxy)ethoxy)ethan amine: The mixture of mCNT 3 (50 $\mathrm{mg})$ and anhydrous 2-(2-(2-aminoethoxy)ethoxy)ethanamine $(120 \mathrm{ml})$ was heated at 100 -C for $100 \mathrm{~h}$. During this time, the liquid phase became dark. After cooling, the mixture was poured into methanol $(100 \mathrm{ml})$ and centrifuged to give a black solid, which was washed several times with methanol. The resulting solid was dried overnight in a vacuum oven at $80 \circ \mathrm{C}$ to give $\mathrm{mCNT} 4(42 \mathrm{mg})$ (figure 1$)$.

4. Labeling with FITC: A suspension of the mCNT $4(25 \mathrm{mg})$ and FITC $(5 \mathrm{mg})$ in anhydrous DMF $(10 \mathrm{ml})$ was stirred in the dark for $5 \mathrm{~h}$. Then the reaction mixture was poured into anhydrous ethyl ether $(40 \mathrm{ml})$ and centrifuged to give a black solid, which was washed with methanol until TLC $(10 \% \mathrm{MeOH}$ in dichloromethane) showed no free FITC left. The product was dried overnight in a vacuum oven at $80{ }^{\circ} \mathrm{C}$ to give mCNT 5 (23 mg) (figure 1).

\subsection{Magnetic-field driven HSPC uptake of FITC-mCNT}

CD $34^{+}$cells with a density of 2.5 to $3^{*} 10^{5}$ cells/plate were placed in poly-L-lysine $(10 \mu \mathrm{g} / \mathrm{ml})$ coated p35 mm culture dishes and incubated for $45 \mathrm{~min}$ at $37{ }^{\circ} \mathrm{C}, 5 \% \mathrm{CO}$. The magneticfield-driven delivery method was applied as previously described [3]. Culture dishes were vertically placed into a beaker containing $50 \mathrm{ml}$ serum-free IMDM media with different concentrations of FITC-mCNT or mCNT $(10,20$ and $40 \mu \mathrm{g} / \mathrm{ml})$ and then the beaker was placed on a magnetic stirrer set up at $1200 \mathrm{rpm}$ for $10 \mathrm{~min}$. Culture dishes were then transferred to an $\mathrm{Nd}-\mathrm{Fe}-\mathrm{B}$ permanent magnet for another $10 \mathrm{~min}$. The uptake experiment was terminated by washing the cells with PBS and the cells were incubated for 1, 3, 6, 24 and $48 \mathrm{~h}$ at $37{ }^{\circ} \mathrm{C}, 5 \% \mathrm{CO} 2$ for uptake efficiency of FITC-mCNT.
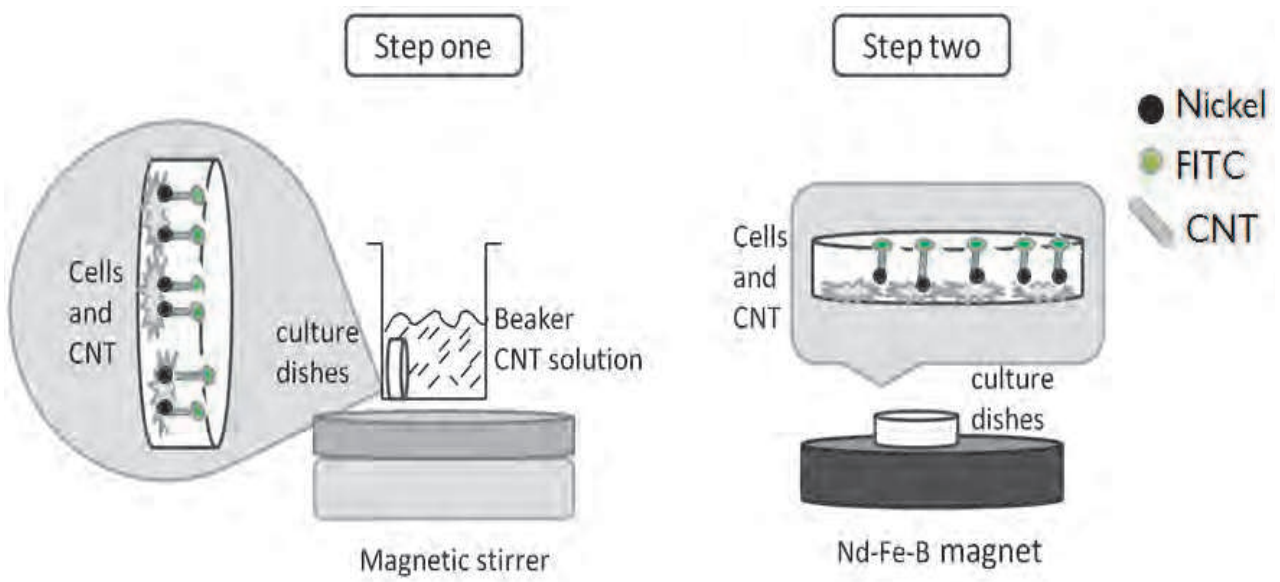

Fig. 2. Schema of magnetic-filed driven delivery method. 


\subsection{FACS analysis}

The cells exposed to FITC-mCNT at different time points and concentrations were collected, extensively washed and then fixed in 1\% paraformaldehyde prior to FACS analysis (FACscan, Becton-Dickinson, San Jose, CA, USA) to determine uptake efficiencies.

\subsection{Confocal microscopy}

CD $34^{+}$cells were seeded at a density of $1^{*} 10^{5}$ cells $/ \mathrm{cm}^{2}$ on cover slips previously coated with poly-L-lysine $(10 \mu \mathrm{g} / \mathrm{ml})$ for $45 \mathrm{~min}$ at $37{ }^{\circ} \mathrm{C}, 5 \% \mathrm{CO}_{2}$. The cells exposed to $40 \mu \mathrm{g} / \mathrm{ml}$ FITC-mCNT and mCNT (the control) with the nanotube spearing method. Uptake was terminated by washing the cells twice with ice-cold PBS. After 1, 3 and $6 \mathrm{~h}$ incubation, the cells were fixed in $3.7 \%$ paraformaldehyde, stored overnight at $4{ }^{\circ} \mathrm{C}$ and examined under an inverted confocal laser scanning microscope (Carl Zeiss LSM510, Toronto, Canada) equipped with imaging software (LSM 5 Image Browser, Carl Zeiss).

\subsection{Cell viability}

Cell viability was measured by the trypan blue exclusion assay. CD34 ${ }^{+}$cells were collected and pelleted by centrifugation at $700 \mathrm{~g}$ for $5 \mathrm{~min}$. The cells were re-suspended in $25 \mu \mathrm{l}$ phosphate buffered saline (PBS), mixed with $5 \mu \mathrm{l}$ of $0.4 \%$ trypan blue solution and counted using a hemocytometer.

\subsection{Colony-forming unit (CFU) assay}

After exposure to the FITC-mCNT solution with a concentration of $40 \mu \mathrm{g} \mathrm{ml}-1$ for 1,3 and 6 $\mathrm{h}, \mathrm{CD}_{3}{ }^{+}$cells were plated in triplicate in standard semisolid methylcellulose haematopoietic progenitor culture media (human MethoCult GF; Stem Cell Technologies, Vancouver, BC, Canada) at concentrations of $1^{*} 10^{3} / \mathrm{ml}$ These culture plates were incubated at $37{ }^{\circ} \mathrm{C}$ in $5 \% \mathrm{CO}_{2}$. Colonies were identified and enumerated 14 days later.

\section{Results and discussion}

In the present study, we examined the magnetic-field-driven uptake of FITC-mCNT into HSPC. FITC-mCNT with both fluorescent and magnetic properties were synthesized and freshly prepared for our uptake experiments as summarized in figure 1 . In order to test our fluorescent and magnetic FITC-mCNTs for labelling HSPC, CD $34^{+}$cells obtained from LP were exposed to solutions of different concentrations of FITC-mCNT or mCNT alone (10, 20 and $40 \mu \mathrm{g} / \mathrm{ml}$ ) in the presence of a magnetic field. The uptake efficiencies of these cells were determined using FACS 1, 3 and $6 \mathrm{~h}$ after the uptake. In LP CD34+ cells, the FITC-mCNT uptake started (45\% FITC uptake) $1 \mathrm{~h}$ after exposure even at the lowest FITC-mCNT concentration $(10 \mu \mathrm{g} / \mathrm{ml}$ and reached its maximum efficiency (83\% FITC uptake) after $6 \mathrm{~h}$ (figure 3(A)).

FITC reached $83 \%, 90 \%$ and $100 \%$ in LP CD34+ cells at $6 \mathrm{~h}$ after uptake of FITC-mCNT with 10, 20 and $40 \mu \mathrm{g} / \mathrm{ml}$ concentrations, respectively. Although LP CD34+ cells were $\sim 100 \%$ FITC-positive at 3 and $6 \mathrm{~h}$ after uptake of FITC-mCNT $(40 \mu \mathrm{g} / \mathrm{ml})$, the mean fluorescence (MF) was the highest at $6 \mathrm{~h}$ after FITCmCNT uptake (figure 3(B)), which indicates more uptake of FITC-mCNT into CD34 ${ }^{+}$cells as time increases. Therefore, we further investigated the internalization of the highest concentration of FITC-mCNT $(40 \mu \mathrm{g} / \mathrm{ml})$ into these cells at 24 and $48 \mathrm{~h}$ after uptake. LP CD34+ cells were still about $98 \%$ FITC-positive 24 and $48 \mathrm{~h}$ after FITC-mCNT uptake, though their MF significantly dropped compared to that at $6 \mathrm{~h}$ (figure 4), most likely due to FITC degradation over time. 


\section{A}

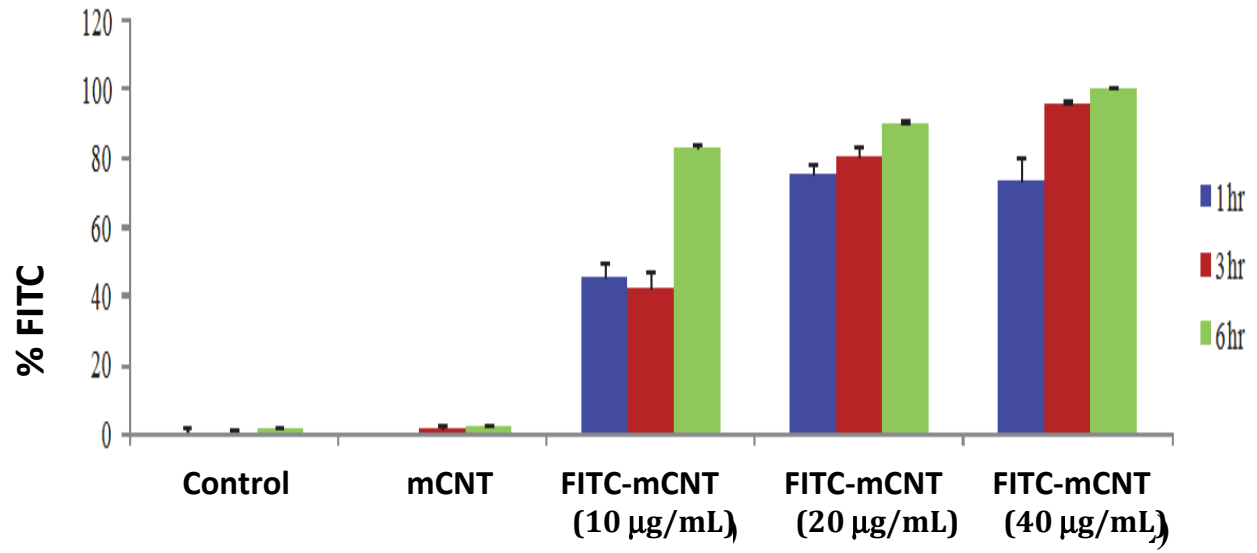

B

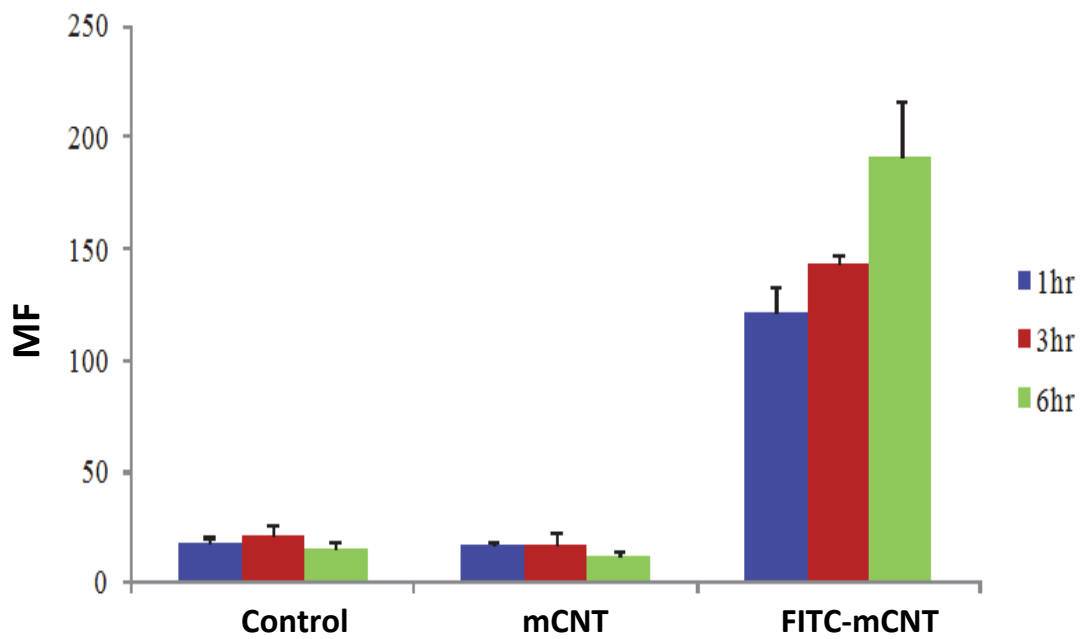

Fig. 3. Efficient uptake of FITC-mCNTs in LP HSPC as shown by FACS analysis. (A) \% FITC of LP CD34+ cells exposed to increasing concentrations of FITC-mCNTs or mCNTs $(10,20$ and $40 \mu \mathrm{g} / \mathrm{ml}$ ) at 1, 3 and $6 \mathrm{~h}$ after exposure. (B) Mean fluorescence of LP CD34+ cells exposed to FITC-mCNT $(40 \mu \mathrm{g} / \mathrm{ml})$ at 1,3 and $6 \mathrm{~h}$ after delivery. 


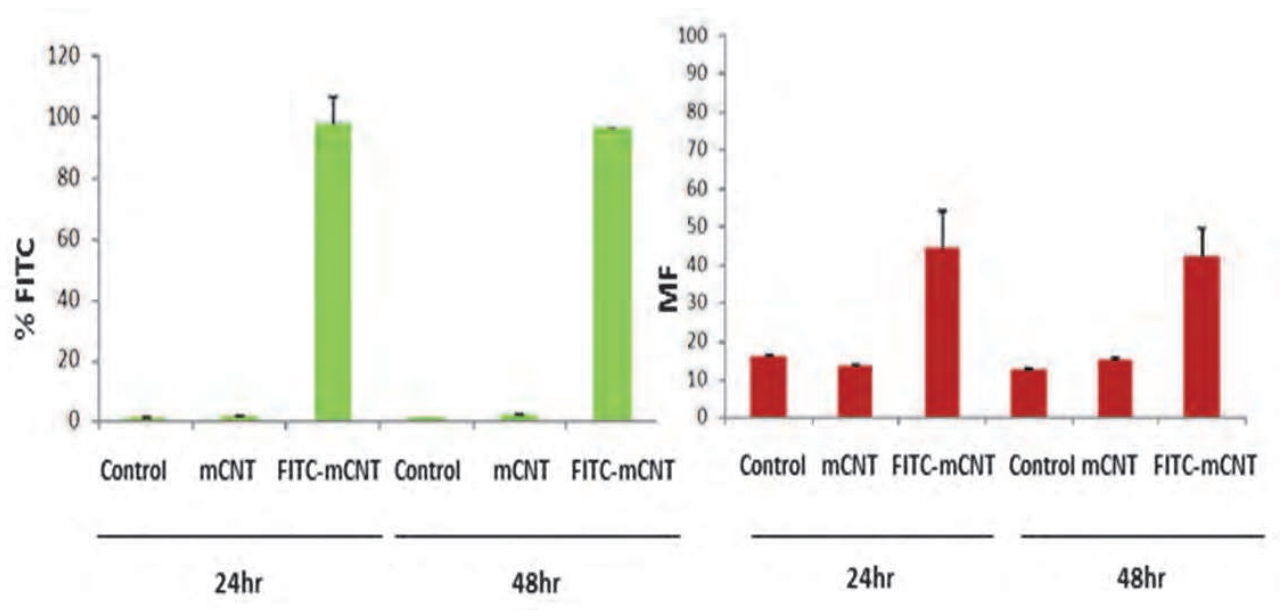

Fig. 4. \% FITC and MF of LP CD34+ exposed to FITC-mCNT $(40 \mu \mathrm{g} / \mathrm{ml}) 24$ and $48 \mathrm{~h}$ after delivery.

To confirm that even less mature HSPC can efficiently uptake FITC-mCNT, we next studied the internalization of FITC-mCNT $(40 \mu \mathrm{g} /$ mlinto CB-derived HSPC containing a larger immature stem cell fraction (CD34+, CD38-phenotype) than LP HSPC. The efficient uptake started after about $1 \mathrm{~h}$ in CB CD34 ${ }^{+}$cells as demonstrated by $\sim 40 \%$ FITC uptake rate shown in figure 5(A), which was lower compared to the result in LP CD34+ cells. FITC-mCNT uptake reached $90 \%$ about $6 \mathrm{~h}$ after its exposure to the cells, similar to the result in LP CD34 ${ }^{+}$ cells, based on the FACS analysis (figure 5(A)). Confocal analysis also confirmed the efficient internalization of FITC-mCNT into CB CD34+ cells (figure 5(B)), similar to confocal data obtained in THP-1 and MCF-7 cells [25]. FITC-mCNT uptake was saturated at $6 \mathrm{~h}$ after its exposure to $\mathrm{CB}$ CD34 ${ }^{+}$cells similar to $\mathrm{LP}^{\mathrm{CD}} 34^{+}$cells (figure 5(B)). However, we did not observe a fluorescence signal by confocal analysis $1 \mathrm{~h}$ after FITC-mCNT exposure to cells, most probably due to a weak fluorescence signal (data not shown). The HSPC that were not exposed to FITC-mCNT (or the control) did not show any evidence of green fluorescence by confocal analysis, which is consistent with the FACS data in figure 5(B). These data suggest that FITC-mCNT are efficiently internalized by HSPC in a time and concentrationdependent manner. In addition, this efficient mCNT delivery method does not depend on a targeted cell type because this method employs a physical magnetic force for delivery, unlike a biological mechanism like viral. Compared with other nanomaterial uptake using native or modified supermagnetic iron oxide (SPIO) [26, 27], FITC-mCNT labelling or uptake is more efficient for stem cell labelling.

Our rapid FITC-mCNT labelling of HSPC might offer a solution for the difficulty of tracking the movement of transplanted HSPC in patients.

To investigate the cytotoxicity of mCNT, we studied the HSPC viability after FITC-mCNT uptake by trypan blue exclusion assay. With the exposure of FITC-mCNT to various concentrations $\left(10,20\right.$ and $40 \mu \mathrm{g} / \mathrm{ml}$, the viability of LP CB CD34 ${ }^{+}$cells was not compromised compared to the control even $6 \mathrm{~h}$ after delivery when the uptake rate reached its peak in these cells (figure 6(A)). As expected, the viability of CB CD34+ cells was also not affected by the uptake of FITC-mCNT (figure 6(B)). 

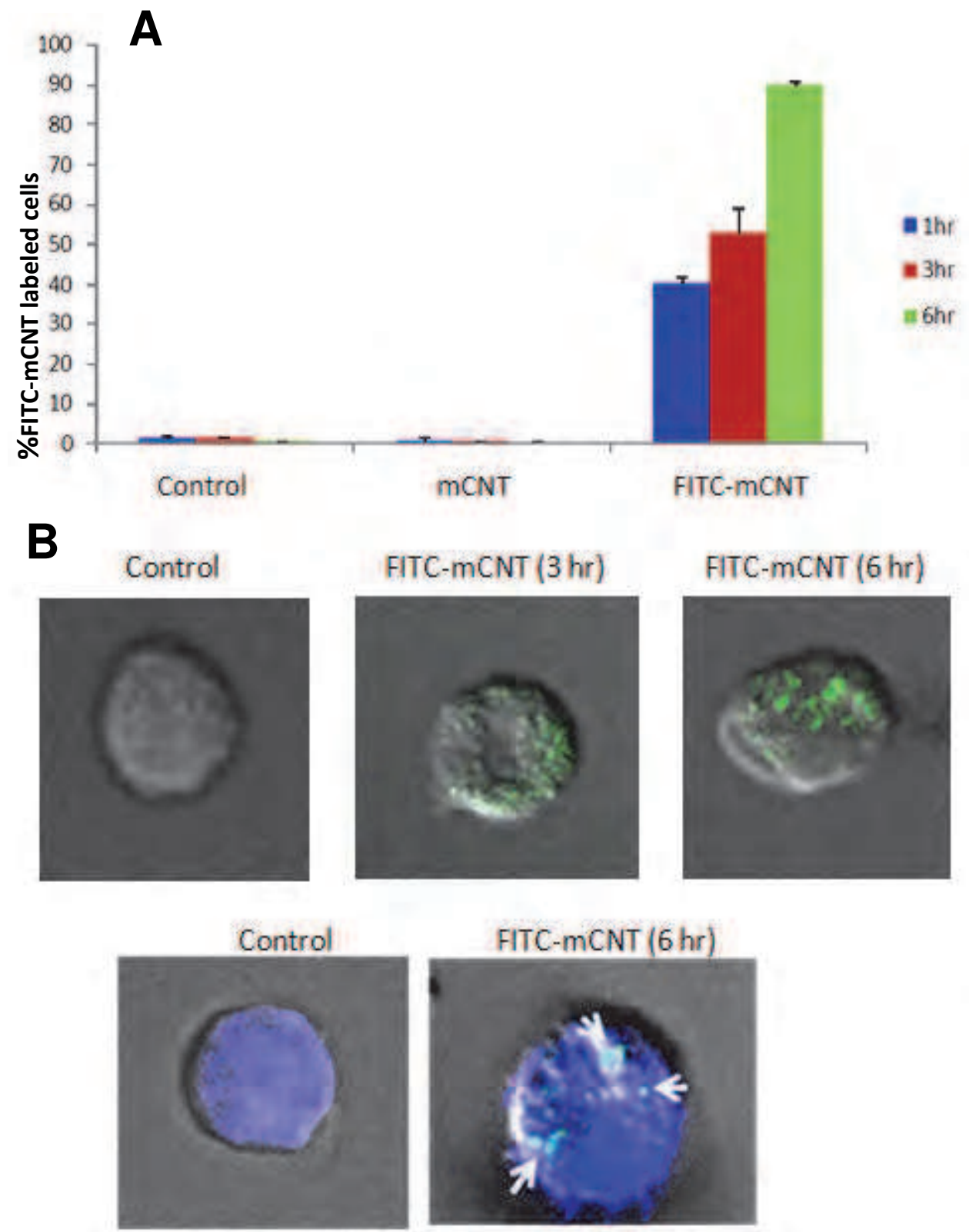

Fig. 5. FITC-mCNTs are also taken up effectively into CB HSPC. (A) \% FITC of CB CD34+ cells labelled with FITC-mCNT $(40 \mu \mathrm{g} / \mathrm{ml})$. (B) Confocal microscopy of FITC-mCNTlabelled $\mathrm{CB} C \mathrm{CD} 34^{+}$cells at 3 and $6 \mathrm{~h}$ after delivery. Blue (DAPI): nucleus. 


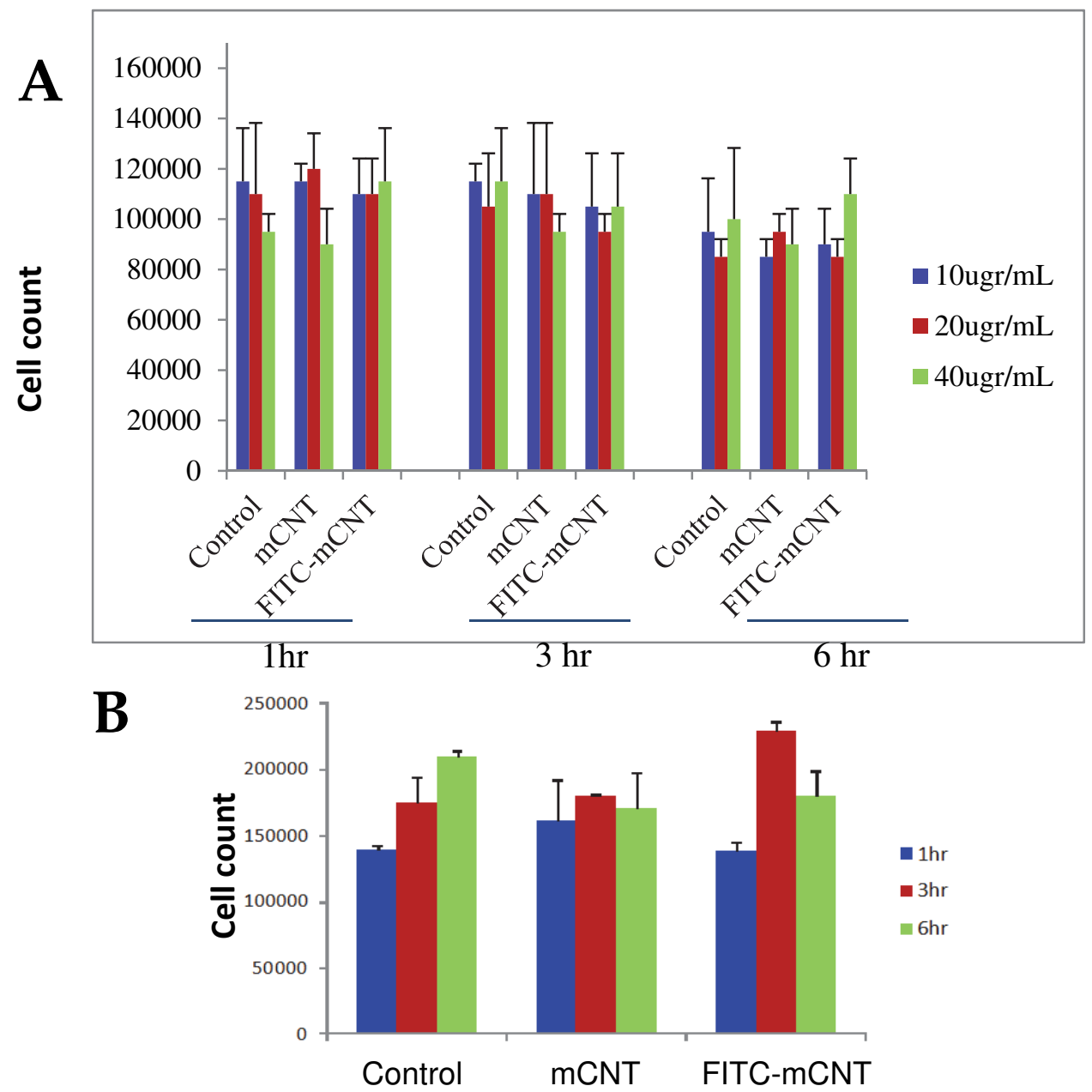

Fig. 6. FITC-mCNTs show no adverse effect on cell viability of HSPC cell count of FITCmCNT-labelled (A) LP CD34+ cells and (B) CD34+ cells

It has been reported that CNT has no adverse effect on macrophages. It was also not cytotoxic and has no significant effect on adipogenic, osteogenic or chondrogenic differentiation of hMSC [28]. To investigate the long-term cytotoxicity effect of our magnetic-field-driven FITC-mCNT uptake and their impact on the differentiation of HSPC, we performed a colony unit assay (CFU) on FITC-mCNT-labelled HSPC 1, 3 and $6 \mathrm{~h}$ after uptake. After 14 days, colonies were identified and enumerated. No evidence was observed of cytotoxicity nor was the differentiation affected in FITC-mCNT labelled HSPC because there was no difference in overall colony number or type (CFU-GM: colony-forming unit of granulocyte/macrophage; BFU-E: burst forming unit of erythrocyte; CFU-GEMM: colonyforming unit of granulocyte macrophage-erythroid megakaryocyte) between the FITC- 
mCNT labelled and the control HSPC (figure 7). These observations suggest that FITCmCNT internalization is not only efficient and safe, but it also does not alter the HSPC's properties, similar to the effect of $\mathrm{COOH}$-functionalized single-walled $\mathrm{CNT}$ in human mesenchymal stem cells [28].

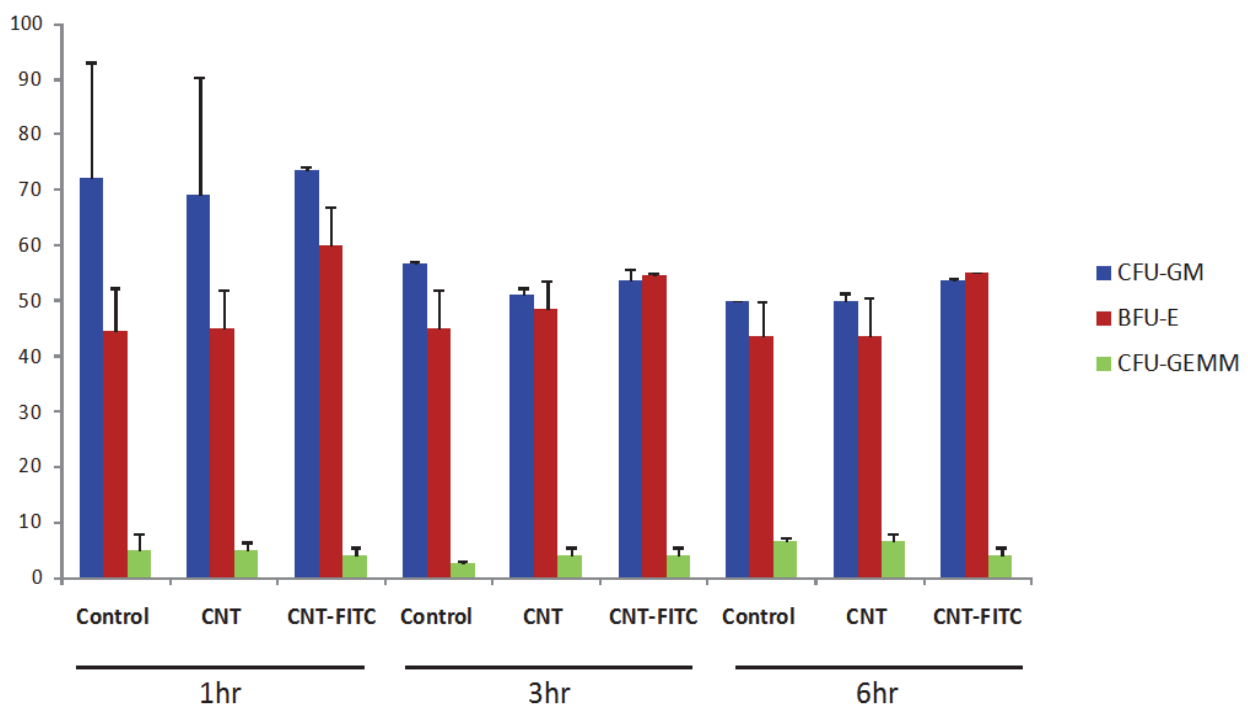

Fig. 7. Internalization of FITC-mCNTs did not affect the differentiation of HSPC. Colonyformation unit of FITC-mCNT-labelled HSPCs at 1, 3 and $6 \mathrm{~h}$ after the internalization by clonogenic assay.

\section{Conclusion and future outlook}

In the current study, a highly efficient and safe mCNT-mediated labelling method for stem cells has been presented. For the efficacy of future stem cell-based therapies, it is crucial to image stem cells and their final location in vivo. Detection by magnetic resonance imaging (MRI) may serve as a noninvasive in vivo method to study the fate of transplanted stem cells labelled with magnetic nanoparticles. However, the detection of mCNT by standard MRI would be difficult due to its low resolution. Thus, mCNT modified with a contrast agent such as gadolinium chelates could be used for in vivo detection and tracking of stem cells using MRI. A promising new approach to non-invasive imaging by exploiting the nearinfrared (NIR) optical properties of mCNT might also create significant advances for in vivo monitoring of transplanted stem cells. In addition to their use for stem cell labelling and tracking, mCNT could also serve as a perfect platform to deliver genes into hard-to-transfect stem cells. Many strategies for enhancing stem cell transplantation, proliferation and differentiation require the delivery of biomolecules into the cytosolic or nuclear compartments. However, transfection efficiency in stem cells is very low -- a consequence of the low division frequency of the target cells and the quiescent nature of most primitive stem cells. Though viral vectors are capable of efficiently transporting recombinant DNAs 
into a cell, the undesirable consequences of a viral integration process (i.e. haphazard activation or silencing of host genes), as well as the immunogenicity of viral particles, have recently raised safety concerns about viral vectors [29]. mCNTs that cross the cell membrane through mechanisms other than endocytosis might be an interesting approach to deliver biomolecules within stem cells. Therefore, systemic studies must assess the toxicological impacts of nanotubes on a biological system and evaluate the effects of CNT on the function of stem cells in vivo.

\section{Acknowledgments}

The authors would like to acknowledge funding supports from the Canadian Institutes of Health Research (CIHR) and the Industrial Research Assistance Program (IRAP) program of the National Research Council (NRC), Canada. The authors would also like to acknowledge the valuable discussions with Dr Eric Swanson, the Director of the National Research Council (IRAP program), Edmonton, Canada.

\section{References}

[1] Klumpp C, Kostarelos K, Prato M and Bianco A 2006 Biochim. Biophys. Acta-Biomembr. 1758 404-12

[2] Pantarotto D, Singh R, McCarthy D, Erhardt M, Briand J P, Prato M, Kostarelos K and Bianco A 2004 Angew. Chem. Int. Edn 43 5242-6

[3] Cai D, Mataraza J M, Qin Z H, Huang Z, Huang J, Chiles T C, Carnahan D, Kempa K and Ren Z 2005 Nat. Methods 2 449-54

[4] Bekyarova E, Ni Y, Malarkey E B, Montana V, McWilliams J L, Haddon R C and Parpura V 2005 J. Biomed. Nanotechnol. $13-17$

[5] Davis J J, Coles R J and Hill H A O 1997 J. Electroanal. Chem. 440 279-82

[6] Besteman K, Lee J O, Wiertz F G M, Heering H A and Dekker C 2003 Nano Lett. 3 727-30

[7] Thess A, Lee. R, Nikolaev. P, Diah. H, Petit. P,Robert.J, Xu.C,Fischer.J.E and Samalley.R.E 1996 Science 273 483-7

[8] Bethune.D,Kiang.C,Beyers.R 1993 Nature 363 605-607

[9] Cassell AM, Raymakers JA, Kong J, Dai HJ 1999 J Phys Chem B 103 6484-92

[10] Colvin VL 2003 Nat Biotechnol 21 1166-1170

[11] Bianco A, Kostarelos K, Partidos CD, Prato M 2005 Chem Commun 5 571-577

[12] Kostarelos K, Lacerda L, Partidos CD, Prato M, Bianco A 2005 J Drug Deliv SciTechnol 15 41-47

[13] Bianco A 2004 Expt Opin Drug Deliv 157-65

[14] Kam N W S and Dai H J 2005 J. Am. Chem. Soc. 127 6021-6

[15] Kam N W S, Liu Z A and Dai H J 2006 Angew Chem Int. Edn 45 577-81

[16] Chin S F, Baughman R H and Pantano P 2007 Exp. Biol. Med. 232 1236-44

[17] Leeuw T K, Reith R M, Simonette R A, Harden M E, Cherukuri P T, Tsyboulski D A, Beckingham K M and Weissman R B 2007 Nano Lett. 7 2650-4

[18] Copelan E A 2006 New Engl. J. Med. 354 1813-26

[19] Lu L, Shen R N and Broxmeyer H E 1996 Crit. Rev. Oncol.Hematol. 22 61-78

[20] Kolb H J, Simoes B and Schmid C 2004 Curr. Opin. Oncol. 16 167-73 
[21] Gul H, Marquez-Curtis L A, Jahroudi N, Lo J, Turner A R and Janowska-Wieczorek A 2009 Stem Cells Dev. 18 831-8

[22] Hirsch A 2002 Angew.Chem. Int. Edn 41 1853-9

[23] Baker S E, Cai W, Lasseter T L, Weidkamp K P and Hamers R J 2002 Nano Lett. 2 141317

[24] Balasubramanian K and Burghard M 2005 Small 1 180-92

[25] Lu W, Gul H, Xu P, Ang W T, Xing J, Zhang J and Chen J 2009 Proc. IEEE/NIH Life Science Systems and Application Workshop pp 173-5

[26] Bulte J W and Kraitchman D L 2004 NMR Biomed. 17 484-99

[27] Bulte J W et al 2001 Nat. Biotechnol. 191141-7

[28] Mooney E, Dockery P, Greiser U, Murphy M and Barron V 2008 Nano Lett. 8 2137-43

[29] Uchida N, Sutton R E, Friera A M, He D, Reitsma M J, ChangW C, Veres G, Scollay R andWeissman I L 1998 Proc. Natl Acad. Sci. USA 95 11939-44 


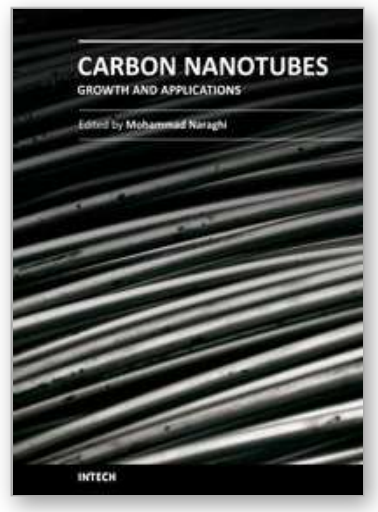

\section{Carbon Nanotubes - Growth and Applications}

Edited by Dr. Mohammad Naraghi

ISBN 978-953-307-566-2

Hard cover, 604 pages

Publisher InTech

Published online 09, August, 2011

Published in print edition August, 2011

Carbon Nanotubes are among the strongest, toughest, and most stiff materials found on earth. Moreover, they have remarkable electrical and thermal properties, which make them suitable for many applications including nanocomposites, electronics, and chemical detection devices. This book is the effort of many scientists and researchers all over the world to bring an anthology of recent developments in the field of nanotechnology and more specifically CNTs. In this book you will find:

- Recent developments in the growth of CNTs

- Methods to modify the surfaces of CNTs and decorate their surfaces for specific applications

- Applications of CNTs in biocomposites such as in orthopedic bone cement

- Application of CNTs as chemical sensors

- CNTs for fuelcells

- Health related issues when using CNTs

\section{How to reference}

In order to correctly reference this scholarly work, feel free to copy and paste the following:

H. Gul-Uludag, W. Lu, P. Xu, J. Xing and J. Chen (2011). Carbon Nanotube-Mediated Labelling Platforms for Stem Cells, Carbon Nanotubes - Growth and Applications, Dr. Mohammad Naraghi (Ed.), ISBN: 978-953-307566-2, InTech, Available from: http://www.intechopen.com/books/carbon-nanotubes-growth-andapplications/carbon-nanotube-mediated-labelling-platforms-for-stem-cells

\section{INTECH}

open science | open minds

\section{InTech Europe}

University Campus STeP Ri

Slavka Krautzeka 83/A

51000 Rijeka, Croatia

Phone: +385 (51) 770447

Fax: +385 (51) 686166

www.intechopen.com

\section{InTech China}

Unit 405, Office Block, Hotel Equatorial Shanghai

No.65, Yan An Road (West), Shanghai, 200040, China

中国上海市延安西路65号上海国际贵都大饭店办公楼405单元

Phone: +86-21-62489820

Fax: +86-21-62489821 
(C) 2011 The Author(s). Licensee IntechOpen. This chapter is distributed under the terms of the Creative Commons Attribution-NonCommercialShareAlike-3.0 License, which permits use, distribution and reproduction for non-commercial purposes, provided the original is properly cited and derivative works building on this content are distributed under the same license. 